\title{
Accounting Numbers and Stock Prices in the Nigerian Stock Market
}

\section{Adetula Dorcas Titilayo, Obigbemi Imoleayo Salako, Owolabi Folashade and Nwobu Obiamaka}

\author{
Department of Accounting, Covenant University, Ota, Ogun State, Nigeria
}

Correspondence should be addressed to: Adetula Dorcas Titilayo;

dorcas.adetula@covenantuniversity.edu.ng

Received date: 17 March 2015; Accepted date: 17 June 2015; Published date: 16 September 2016

Academic Editor: Tereza Otčenášková

Copyright (C) 2016. Adetula Dorcas Titilayo, Obigbemi Imoleayo Salako, Owolabi Folashade and Nwobu Obiamaka. Distributed under Creative Commons CC-BY 4.0

\begin{abstract}
This research is motivated to study the extent to which accounting information summarizes stock prices in Nigerian stock market as an indicator of value relevance. Piece of accounting data is termed value relevant if it is significantly related to the dependent variable, which may be expressed by the stock price. The methods used for gauging information contents of various accounting numbers were Ordinary Least Squared (OLS), Random Effects Model (REM), and Fixed Effects Model (FEM). The findings show that there is a significant relationship between accounting information and share prices of companies listed on the Nigerian Stock Exchange. Dividends are the most widely used accounting information for investment decisions in Nigeria, followed by earnings and net book value. The study therefore recommends that the firms should improve the quality of earnings as manipulated earnings (of which dividends are sub-sets) have large effects on share prices. The paper also recommends that all companies listed on the Nigerian Stock Exchange should prepare Simplified Investor's Summary Accounts (SISA) with emphasis on the most widely used accounting information along the required mandatory detailed financial statements to suit Nigerian peculiarities. The study's findings and recommendations may be of use to National Standard Setters, preparers of accounting information, Nigerian Stock Exchange Regulators, investors and other emerging stock market.
\end{abstract}

Keywords: Value Relevance, Accounting Information, Investors, Financial Statement

Cite this Article as: Adetula Dorcas Titilayo , Obigbemi Imoleayo Salako, Owolabi Folashade and Nwobu Obiamaka (2016),"Accounting Numbers and Stock Prices in the Nigerian Stock Market", Journal of Accounting and Auditing: Research \& Practice , Vol. 2016 (2016), Article ID 252697, 


\section{Introduction}

Accounting provides a vital service to broad and different users. Investors use financial accounting information for investment decisions; government agencies need it particularly for tax purposes; while regulatory agencies use it to determine whether existing statutory pronouncements are complied with, among others. According to Meyer (2007:2) "accounting plays a significant role within the concept of generating and communicating wealth of companies". Financial statements still remain the most important source of externally feasible information on companies. Nevertheless, in the wake of the recent accounting scandals and economic meltdown, where billions of naira of investment and retirement wealth have disappeared, the very integrity and survivability of value relevance of accounting service has been called into question. Value relevance of accounting information is defined as the ability of accounting numbers, contained in the financial statements, to explain the stock market measures (Beisland, 2009). Accounting data, such as earnings per share, are termed value relevant if they are significantly related to the dependent variable, which may be expressed by price, return or abnormal return (Gjerde, Knivsfla and Saettem, 2007).

Studies on value relevance of accounting information are motivated by the fact that listed companies use financial statements as one of the major media of communication with their equity shareholders and public at large (Vishnani and Shah, 2008). For instance, in Nigeria, Companies and Allied Matters Act (CAMA) (1990) require the Directors of all companies listed on the Nigerian Stock Exchange (NSE) to prepare and publish annually the financial statements of their organizations. Beyond this, the Nigerian Stock Exchange mandates all companies listed on first tier market to submit quarterly, semi-annual and annual statements of their accounts to the Stock Exchange and companies on second tier market are to submit their statements of accounts annually to Stock Exchange. This study investigates whether these various items of financial statements are value relevant in Nigerian Stock Market. The Nigerian Stock Exchange (NSE) commenced operation in 1961with only 19 securities worth N80million. In 2007, the NSE hit an all-time high market capitalization of US $\$ 82$ billion at end of 2007(Kumo, 2008). The amount is double the foreign reserve of Nigeria at the time. In addition, during those years, the Nigerian Stock Market recorded a significant rise in activity and share prices rose considerably only to collapse in the second half of 2008. Before this collapse, the number of listed securities had increased to 299, made up of 86 Government Stocks with Industrial Loans Stocks and 213 Equity/ Ordinary Shares(including emerging market) with a total market capitalization of N13.295 trillion (The NSE Factbook, 2009). The study therefore focuses on the period before and immediately after this collapse. It covers a period of 7 years from 2002 to 2008. The choice of this period is necessitated by rapid growth in Nigerian stock market from 2002 to 2007 and the abrupt collapse in 2008. Before this collapse, investors were all enjoying the boom in the Nigerian stock market, making tremendous returns as stock prices soared to unprecedented levels.

This research is motivated to study the extent to which accounting information summarizes stock prices in Nigerian stock market as an indicator of value relevance. While there have been a number of studies on this topic in developed countries (Collins, Maydew and Weiss, 1997; Francis and Schipper, 1999 and Beisland, Hamberg and Navak, 2010), the study is not aware of any expansive study that has explored the subject of value relevance of 
accounting information in Nigeria. It has not been comprehensively researched primarily because of problems with data availability (Negah, 2008). The specific objective of the paper, based on the identified problems is to investigate whether accounting information has the ability to capture or summarize information that affects share prices of firms listed on the Nigerian Stock Exchange. The paper is divided into a number of sections. Following the introduction to the study are literature review, research methodology, findings and recommendations.

\section{Literature Review}

Over four decades ago, value relevant of accounting information became the focus of accounting research. Ball and Brown (1968) provide evidence of security market reaction to earnings announcements. On the basis of their studies, they claim that accounting information is useful to investors in estimating the expected values and risks of security returns. Their result shows that earnings are value relevant. However, in recent times, stock markets research in accounting has witnessed increasing attacks on the value relevance of accounting information. A number of literatures in the developed countries have created a widespread notion that accounting numbers have lost their value relevance (Ramesh and Thiagarajan, 1995; Dontoh, Radhakrishnan and Ronen, 2001). These criticisms were based on theory of life cycle stages, high-technology, fraud, rapidly changing business environment, increasing conservatism and frequent use of coefficient of determination in accounting research as a measure of value relevance without controlling for differences in the coefficient of variation of scale factor (Brown, Lo and Lys, 1999) among others. This belief also developed in response to claims of traditional financial statements losing relevance because of the move from an industrialized economy to a high-tech, service oriented economy (Collins, Maydew \& Weiss, 1997). These findings were supported by past studies that investigated the association between accounting numbers and stock prices and showed that, in most cases, the association between counting data and stock prices has been declining over time (Francis and Schipper, 1999; Brown, Lo and Lys, 1999; Lev and Zarowin, 1999).

Nevertheless, such views have met with stiff opposition with studies such as Collins, Maydew and Weiss, (1997) asserting that it is premature to claim that accounting information has lost its value relevance. Balachandran and Mohanram (2006) in a recent study of association between conservatism and the value relevance of accounting information, conclude that there is no evidence that industries with increasing conservatism see a greater decline in value relevance than industries with deceasing conservatism. Furthermore, Callao, Cuellar and Jarne (2006) perform a comparative analysis of the value relevance of reported earnings and their components. Their study provides evidence for the value relevance of net earnings figure. Gjerde, Knivsfla and Saettem (2007) find that the time trend of overall value-relevance has not declined after controlling for changes in underlying economic variables. Frost and Powall (1994) compare the stock market reaction to the annual and quarterly earnings in the U.S. and U.K. They report greater market reactions to earnings in the U.S. and attribute this to high liquidity and more frequent information disclosure in U.S. market. They also report that the market reaction to earnings announcements by the same multinational corporation is different between the U.K and the U.S. Their results suggest that that the investors in different countries react to the same earnings announcement in different ways.

The importance of financial accounting information in stock market growth can 
best be appreciated by examining how well accounting information numbers such as earnings explain or impact on stock prices and returns. Research indicates that share price is a factor that is "priced" in the securities market (Blume and Husic, 1973). The share price impact appears to subsume both the earnings yield and size effects upon abnormal security returns. The research also indicates that share price has a strong cross-sectional association with security returns. Covill (1998) investigate relationship between changes in earnings per share and the performance of the market. He employs linear correlation coefficient and inferred that changes in average earnings per share over five years might be a good predictor of average changes in stock prices over the next five years. Salmi, Virtanen, Yli-Olli and Kallunki (1997) claim there is a clear relationship between the firm's accounting and stock-market variables. Ariff, Loh and Chew (1997) also report relationship between earnings and share prices. Their results show that unexpected earnings changes are significantly associated with share price changes.

Nearly all evidence in the area of value relevance of accounting information is obtained from the developed stock markets and these include Ball and Brown (1968), Pankoff and Virgil (1970) and Francis and Schipper (1999). However, Nigerian stock market is an emerging one (Kumo, 2008). The Nigerian stock market is an emerging capital market due to the rate and prospects of its growth (Osaze, 2007). He claims that Nigerian stock market is still poorly developed though emerging. Emerging markets are now a very important key determinant of global growth. The International Finance Corporation in 1980 coins emerging market to refer to developing countries with stock markets that are beginning to demonstrate the features of mature stock markets in the industrial countries. Nellor (2008) defines emerging markets as "countries in sub-Saharan Africa that have financial markets and attract investors' interest". He avers that emerging markets are attractive to investors because they offer rates of return that are high relative to developed markets and proffer for investors to diversify risk. There are a number of researches in Nigeria on relation between Nigerian stock market and economic growth (Babatunde and Mokuolu, 2005, Ologunde, Elumilade and Asaolu, 2006); however, at the time of this research, there is no extensive work on relation between accounting information and Nigerian stock market growth.

\section{Research Methodology}

Two major approaches were used in the previous related studies to evaluate the value relevance of accounting information - aggregate stock market reaction and individual investors' reaction to accounting information. These are synonymous with measurement and informational perspectives respectively. This study adopted the aggregate stock market reaction. The study made use of secondary data to investigate the aggregate Nigerian stock market reaction to accounting numbers following Bernard (1995); Brief and Zarowin (1999); Barth, Beaver and Landsman (2000) and Beisland (2009). Study population consisted of all the listed companies on the Nigerian Stock Exchange. The total number of two hundred and thirteen companies was listed on the Nigerian Stock Exchange as at 2008 (The Nigerian Stock Exchange Factbook, 2009:34). However, the study focused on 68 companies listed on the Nigerian Stock Exchange during the period - 2002 to 2008. The sample size was limited to 68 companies because of non availability of data. These problems arose either from missing data as a result of de -listing (post-selection bias due, for instance, to bankruptcy) or missing data as a result of initial listing (ex-ante selection bias due to initial listing in emerging market) or acquisition or merger. The problems of 
missing data are peculiar with almost databases, but deemed to be worse in developing economies (Negah, 2008).

Panel data were used to overcome the problems associated with missing data (Negah, 2008). The panel data of 68 companies over a period of 7 years resulted in 476 observations. The firms were selected based on the following criteria: (1) The company was listed on the Nigerian Stock Exchange during the period and (2) The firm has the basic financial statement data.

The study employed multi-phase sampling method (Phillip and Fetter, 1999). In multiphase sampling, some of the same sampling units are employed at the different phases of sampling. In its simplest form, multiphase sampling is a method in which certain items of information are drawn from the whole units of a sample and certain other items of information are taken from the subsample. In this study, first and foremost, the firms were selected if they were listed and active on the Nigerian Stock Exchange (between January, 2002 and December, 2008). Applying this criterion, the initial sample size was 144 , but reduced further to 68 firms when the criterion of data availability was applied.

\section{Model Specification}

To analyze the importance of accounting information in determining share price in the Nigerian stock market, the model by Ohlson 1995 was adapted. Changes of share price were specified to be explained by earnings per share, dividend per share and net book value. Ohlson (1995) depicts in his work that the value of a firm can be expressed as a linear function of book value, earnings and other value relevant information.

\section{Model 1: Aggregate Market Reaction to Accounting Earnings and Book Value in Equity Valuation}

The functional relationship between share price and the independent variables is specified as:



$L D S P_{i t}$ is stock price, and it is measured in the end of December at year $t+1$. $V R B_{i t}$ is book value of equity per share at fiscal year end and $\mathrm{VRE}_{i t}$ is earnings per share for year $t$.

The above model is usually referred to as being based on the Ohlson (1995) valuation framework

(Francis and Schipper, 1999; and Lev and Zarowin, 1999).

However, this is only partially correct because Ohlson uses residual income, not income itself, in his valuation model. Specification (1) is only consistent with Ohlson's valuation model if one admits earnings as being a proxy for residual income. Nonetheless, current earnings do have an association with value and past empirical studies confirm the model's functionality.

\section{Model 2: Aggregate Market Reaction to Accounting Dividends and Book Value in Equity Valuation}

The model is specified in an implicit form: LDSP $_{\mathrm{i} t}$ $=$ $f\left(V R D_{\mathrm{i} t}, V R B V_{\mathrm{i} t}\right)$

Where, LDSP = Last Day Price per share $V R D=$ Dividends per Share $V R B V=$ Book Value per Share $\mathrm{t}=$ Time dimension $i$ : individual firm 
APriori Expectation is such that $\beta>0$ (i=1-

2). Positive relationship was assumed between accounting information and equity valuation because accounting information is presumed to be a crucial input into share valuation, it would be a surprise if no relationship or reaction could be measured (Penman,1998).

Equations (1) and (2) can be expressed in functional form as follows:

$\operatorname{LDSP}_{i t}=\beta_{0}+\beta_{1} V R E_{i t}+\beta_{2} V R B V_{i t}+$

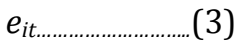

for $i=1,2 \ldots, \mathrm{N}$ cross-section units and periods $t=1,2 \ldots . \mathrm{T}$

Where LDSP is the dependent variable; $\beta_{0}$, $\beta_{1}, \beta_{2}$, are regression coefficients with unknown values; $V R E$ and $V R B V$ are the independent variables and e is a random error component.

$\operatorname{LDSP}_{i t}=\beta_{0}+\beta_{1} V R D_{i t}+\beta_{2} V R B V_{i t}+$ $e_{i t}$ (4) for $i=1,2 \ldots, \mathrm{N}$ cross-section units and periods $t=1,2 \ldots . \mathrm{T}$

Where LDSP is the dependent variable; $\beta_{0}, \beta_{1}, \beta_{2}$, are regression coefficients with unknown values to be estimated; $V R D$ and $V R B V$ are the independent variables and the error term $\left(e_{i t}\right)$ is used as surrogate for all other variables not included.

\section{Method of Analysis}

In this study, our method of gauging information content of various accounting numbers panel as stated in equations (3) and (4) were Ordinary Least Square (OLS), Random Effects Model (REM) and Fixed Effects Model (FEM). OLS was used as a basis of comparison with the previous studies. Chang, Chen, Su and Cha, (2008), claim that stock prices and earnings are usually non-stationary. As a result of nonstationarity of data, FEM and REM were employed. 
Table 1 Results of Model 1: Aggregate Market Reaction to Accounting Earnings and Book Value in Equity Valuation

Dependent Variable: LDSP

\begin{tabular}{|c|c|c|c|c|c|c|}
\hline Estimator & OLS & & FE & & $\mathrm{RE}$ & \\
\hline Variable & Coef & Prob & Coef & Prob & Coef & Prob \\
\hline VRE & $\begin{array}{l}.1073168^{*} \\
(8.99)\end{array}$ & 0.000 & $\begin{array}{l}.028978^{*} \\
(3.19)\end{array}$ & 0.002 & $\begin{array}{l}.0380333^{*} \\
(4.27)\end{array}$ & 0.000 \\
\hline VRBV & -.00004 & $\begin{array}{l}0.963(- \\
0.05)\end{array}$ & $.0005757(0.96)$ & 0.335 & $.0005402(0.91)$ & 0.361 \\
\hline Cons & $\begin{array}{l}10.34729^{*} \\
(5.85)\end{array}$ & 0.000 & $\begin{array}{l}15.19569^{*} \\
(14.70)\end{array}$ & 0.000 & $\begin{array}{l}14.86891^{*} \\
(4.17)\end{array}$ & 0.000 \\
\hline $\mathrm{R}^{2}$ & 0.1602 & & & & & \\
\hline $\operatorname{Adj} R^{2}$ & 0.1564 & & & & & \\
\hline Prob. F & $0.0000^{*}$ & & & & & \\
\hline $\mathrm{R}^{2}$ within & & & 0.0310 & & 0.0308 & \\
\hline $\mathrm{R}^{2}$ between & & & 0.2347 & & 0.2446 & \\
\hline $\mathrm{R}^{2}$ overall & & & 0.1500 & & 0.1546 & \\
\hline Wald Ch2 & & & & & 20.58 & \\
\hline Prb.Ch2 & & & & & $0.000^{*}$ & \\
\hline Hausman Test & & \multicolumn{3}{|c|}{$\begin{array}{l}\text { chi2(2) } 29.88 \\
\text { Prob }>\operatorname{chi} 2=0.0000^{*}\end{array}$} & & \\
\hline No of obser. & 449 & 449 & & & 449 & \\
\hline
\end{tabular}

Note: $\quad *$ significant at the $1 \%$ level

Numbers in parentheses are $t$-values

$\mathrm{Z}$ test in Prentices, bold face and italicized

LDSP = Last trading day share price; VRE = Earnings per Share; VRBV = Net Book Value

LDSP are stated in naira while VRD and VRBV are in kobo

Source: by the researchers

\section{Analysis and Interpretation of Results}

Table 1 shows the results of all applied variables in the analysis of model1. The table presents the results of Ordinary Least Square (OLS), Fixed Effect (FE) and Random Effect (RE) for the Aggregate Market Reaction to Accounting Earnings and Book Value in Equity Valuation. In this model, earnings (VRE) are highly significant at $1 \%$ level in explaining share price. The output of OLS indicates that VRE has a larger regression coefficient, absolute terms than Net book value (VRBV). Beta value measures the degree to which each of the explanatory variables affects the dependent variables. Using OLS, the coefficient of VRE is 0.107. It means that a unit change in earnings will lead to approximately 11 kobo change in share price. In other words, 1 kobo change in earnings will lead to approximately 11

Adetula Dorcas Titilayo , Obigbemi Imoleayo Salako, Owolabi Folashade and Nwobu Obiamaka (2016), Journal of Accounting and Auditing: Research \& Practice, DOI: 10.5171/2016.252697 
kobo change in share price. This is because share prices are stated in Naira while earnings are stated in kobo. However, earnings has low regression coefficient when FE and RE are employed. The regression coefficients when $\mathrm{FE}$ and $\mathrm{RE}$ are employed are 0.028978 and 0.038033 respectively, both are significant at $1 \%$ levels. This implies that a unit (1 kobo) change in earnings will lead to 3 kobo change in share price for FE and 1 unit (1 kobo) change in earnings will lead to 4 kobo change share price using RE. With OLS, the Net book value beta coefficient of -.00004 which is not significant. However, this conclusion changes slightly when $\mathrm{FE}$ and RE are used. FE and RE are 0.0005757 and 0.0005402 respectively although not statistically significant. The reason for the insignificance of VRBV could be that the share price does not reflect the actual situation for the firm. Another reason is perhaps most investors in Nigeria still depend on the earnings performance rather than the Net Book Value. Besides, there may be other factors affecting a firm's performance other than the variables used in the study.

The $t$ tests of VRE are 8.99 and 3.19 for OLS and FE; respectively, while the tests of VRBV are -0.05 and 0.96 for OLS and FE; respectively. The purpose of the t-test is to check the individual significance of each explanatory variable. For t test, any value less than 2 is not significant. The $t$ test further confirms that VRBV is not significant in explaining share price. However, $\mathrm{R}^{2}$ is 0.1602 which is higher than both FE and RE. Accounting number is typically deemed to be value relevant if its estimated regression coefficient is significantly different from zero (Holthausen and Watts, 2001). F statistics is 0.000 which is highly significant. This may provide support for the proposition that: first, there is a positive relationship between earnings, book value and stock market in the Nigerian Stock Exchange (NSE). Second, earnings has great information content. The results of Hausman test are: chi2 2 is 29.88 and $\mathrm{P}$ is 0.0000 . This implies that Random Effect (RE) is more efficient than Fixed Effect (FE). Hausman Test is performed to determine the model that is more efficient. If Probability (P) value is significant, then, $\mathrm{RE}$ is more efficient than FE. Also, Wald test provides a likelihood-ratio test of the model's adequacy. The Wald test using Stata presents p-values instead of reporting the critical values (Baum, 2006:93). 
Table 2 Result of Model 2: Aggregate Market Reaction to Accounting Dividends and Book Value in Equity Valuation

Dependent Variable: LDSP

\begin{tabular}{|c|c|c|c|c|c|c|}
\hline Estimator & OLS & & $\mathrm{FE}$ & & $\mathrm{RE}$ & \\
\hline Variable & Coef & Prob & Coef & Prob & Coef & Prob \\
\hline VRD & $\begin{array}{l}.2272854 * \\
(12.79)\end{array}$ & 0.000 & $\begin{array}{l}0.053429^{* *} \\
(2.80)\end{array}$ & 0.005 & $\begin{array}{l}.0934751^{*} \\
\text { (5.31) }\end{array}$ & 0.000 \\
\hline VRBV & $\begin{array}{l}.000569 \\
(0.73)\end{array}$ & 0.463 & $\begin{array}{l}.0006935 \\
(1.17)\end{array}$ & .0 .244 & $\begin{array}{l}.000657 \\
(\mathbf{1 . 1 1 )}\end{array}$ & 0.268 \\
\hline Cons & $\begin{array}{l}9.039735^{*} \\
(5.58)\end{array}$ & 0.000 & $\begin{array}{l}15.17849^{*} \\
(14.08)\end{array}$ & 0.000 & $\begin{array}{l}14.0522^{*} \\
(\mathbf{4 . 4 2 )}\end{array}$ & 0.000 \\
\hline $\mathrm{R}^{2}$ & 0.2740 & & & & & \\
\hline Adj $R^{2}$ & 0.2707 & & & & & \\
\hline Prob. F & 0.0000 & & & & & \\
\hline $\mathrm{R}^{2}$ within & & & 0.0251 & & 0.0244 & \\
\hline $\mathrm{R}^{2}$ between & & & 0.4232 & & 0.4388 & \\
\hline $\mathrm{R}^{2}$ overall & & & 0.2601 & & 0.2713 & \\
\hline Wald Ch2 & & & & & 30.68 & \\
\hline Prb.Ch2 & & & & & $0.000^{*}$ & \\
\hline Hausman Test & & $\begin{array}{l}\text { chi2(2) } \\
\text { Prob }>c\end{array}$ & $\begin{array}{l}2.57 \\
0.0000^{*}\end{array}$ & & & \\
\hline No of obser. & 450 & 450 & & & 450 & \\
\hline
\end{tabular}

Note: $\quad *$ significant at the $1 \%$ level

Numbers in parentheses are $\mathrm{t}$-values

$\mathrm{Z}$ test in Prentices, bold face and italicized

LDSP = Last trading day share price; VRD =Dividends per Share; VRBV = Net Book Value

LDSP are stated in naira while VRD and VRBV are in kobo

Source: by the researchers

Table 2 shows the results of all applied variables in the analysis of model 2 . The table presents the results of Ordinary Least Square (OLS), Fixed Effect (FE) and Random Effect (RE) for the Aggregate Market Reaction to Accounting dividends and Book Value in Equity Valuation. Looking at this result, dividends (VRD) is highly significant at $1 \%$ level in explaining share price. Beta value of OLS which is a measure of the degree to which each of the explanatory variables affects the dependent variables indicates that VRD has a larger regression coefficient, absolute terms than Net book value (VRBV). Using OLS, the coefficient of VRD is 0.227 . It means that a unit (1 kobo) change in dividends will lead to approximately 23 kobo change in share price while VRBV is .000569 which is not significant. However, FE and RE are used, dividends has low regression coefficient. The regression coefficients of $\mathrm{FE}$ and $\mathrm{RE}$ are 0.053 and 0.093 respectively and they

Adetula Dorcas Titilayo , Obigbemi Imoleayo Salako, Owolabi Folashade and Nwobu Obiamaka (2016), Journal of Accounting and Auditing: Research \& Practice, DOI: 10.5171/2016.252697 
are significant at $1 \%$ levels. This implies that a unit (1 kobo) change in dividends will lead to 5 kobo change in share price using FE and 1 unit (1 kobo) change in dividends will lead to 9 kobo change share price employing RE (It is important to note that share prices are in naira while dividends and net book values are kobo). With OLS, Net book value regression coefficient is -.00004 which is not significant. However, this conclusion changes slightly, though not significant, when FE and RE are used. FE and RE are 0.0005757 and 0.0005402 respectively. The reason for the insignificance of VRBV, as in the previous model, could be that the share price does not reflect the actual situation of the firm. Another reason could be that most investors still depend on the earnings of performance rather than the Net Book Value. Besides, there may be other factors affecting a firm's performance other than the variable used in the study.

The $t$ tests of VRE are 8.99 and 3.19 for OLS and FE respectively while the $t$ tests of VRBV are -0.05 and 0.96 for OLS and FE respectively. The $t$ test further confirms that VRBV is not significant in explaining share price. However, OLS R ${ }^{2}$ is 0.1602 and is significant and higher than the overall $\mathrm{R}^{2}$ both FE and RE which are 0.2601 and 0.2713 .

F statistics is 0.000 which is highly significant. F statistics is a measure of joint significance of all explanatory variables of the model used. This may provide support for the proposition that: first, there is a positive relationship between earnings, book value and stock market in the Nigerian Stock Exchange (NSE). Second, earnings have great information content (comparable to net book value) but the overall result shows that dividends have greater information content than both earnings and net book value. More importantly, when book value is a poor indicator of value (for example, due to the presence of unrecognized assets), and when earnings are transitory, dividends have the greatest value relevance of the three measures. Results of Hausman test are: chi $2^{2}$ is 42.57 and $P$ value is 0.0000 . This shows that Random Effect (RE) is more efficient than Fixed Effect (FE).

\section{Conclusion}

The study finds out that there is a significant relationship between accounting information (earnings per share, dividends and net book value) and share price of companies listed on the Nigerian Stock Exchange. Dividends are the most widely used accounting information for investment decisions in Nigeria, followed by earnings and Net Book Value. Accounting number is typically deemed to be value relevant if its estimated regression coefficient is significantly different from zero (Holthausen and Watts, 2001). This may provide support for the proposition that: first, there is a positive relationship between earnings, dividends, book value and equity value in the Nigerian Stock Exchange (NSE). These results are consistent with the findings of previous studies such as Pourheydari, Aflatooni and Nikbakhat (2008) and Beisland, Hamberg and Novak (2010) among others. Second, dividends have great information content (comparable to earnings and net book value). This is, however, contrary to the result of studies in the developed world where it was found out that analysts used Earnings per Share (EPS) as the main basis for valuing shares (Blume and Husic, 1973 and Frost and Powall, 1994).

\section{Recommendations and Policy Implications of the Empirical Findings}

Evidence indicates that accounting information plays a significant role in investment decision making and by implication, stock market development. Then, following the study's findings these recommendations are presented which may be of use to the National Standard 
Setters, preparers of accounting information, Nigerian Stock Exchange Regulators, investors and other emerging stock market:

1. Due to the importance of earnings, dividends and net book value in investment decisions, the study recommends that all companies listed on the Nigerian Stock Exchange should prepare Simplified Investor's Summary Accounts (SISA) with emphasis on the most widely used accounting information along with the mandatory detailed financial statements to suit Nigerian peculiarities. This is expected to remove information over-load of financial statements particularly for nonaccountants and non-financial analysts;

2. National accounting standard setters and preparers of accounting information should gear effort toward improving the quality of earnings of which dividends the most widely used accounting numbers in Nigeria for investment decision- is a sub-set. This could be done by properly defining and reducing earnings management by the national accounting standard setters and preparers of accounting information respectively. This is because earnings management can be defined in different ways thereby making room for creative accounting.

\section{References}

1. Ariff , M., A. L. Loh and Chew, P. M. (1997), "The impact of accounting earnings on stock prices in Singapore," Asia Pacific Journal of Management, 14(1), 1-15.

2. Babatunde, 0.0.and Mokuolu, J.O. (2005), "Stock market development and economic growth in Nigeria: An empirical analysis," Nigerian Journal of Banking and Financial Issues, 6(1), 56-58.

3. Balachandran S.V. and Mohanran, P.S. (2006), Conservatism and the value relevance of Accounting Information, Working paper of University of Columbia.

4. Ball, R. and Brown, P. (1968), "An empirical evaluation of accounting income numbers," Journal of Accounting Research, 6(2), 159-178.

5. Barth, M. E, Beaver, W.H. and Landsman, W. R. (2000) "The relevance of value relevance research," Journal of Accounting Research, 26 (2), 331-352.

6. Baum,C.F. (2006) An Introduction to Modern Econometrics Using Stata, Stata Press, Texas.

7. Beaver, W.H. (1973) "What should be the FASB's objectives?" The Journal of Accountancy, 49 - 56.

8. Beisland, A.E. (2009) Essays on the value relevance of accounting information, Working paper of Norwegian school of Economics and Business Administration.

9. Beisland, L., Hamberg, A. and Novak, J. (2010), "The value relevance across industries: what happened to the new economy?" [Online], [Retrieved May 21, 2010],

http://web.fma.org/Prague/Papers/Value _Relevance_across_Industries.pdf.

10.Bernard, V. (1995) "The feltham-Ohlson framework: Implications for empiricists," Contemporary Accounting Research, (1)(2), 733-747.

11.Blume, M. and Husic, F. (1973), "Price, beta and exchange listing," Journal of Finance, 283 -290.

12.Brief , R. P. and Zarowin, P. (1999), "The value relevance of dividends, book value and earnings," [Online], [Retrieved August 20, 2010], http://web.stern.nyu.edu/ rbrief/zarowi n.pdf. 
13.Brown, S., Lo, K. and Lys, T. (1999), "Use of $\mathrm{R}^{2}$ in accounting research: Measuring changes in value relevance over the last four decades," Journal of Accounting and Economics, 28(2),83-115.

14.Callao, S., Cuellar, B. and Jarne, J. I. (2006), " International differences in value relevance of accounting data and explaining country factors," International Journal of Accounting, Auditing and Performance Evaluation, 3(4), 387-408.

15.Chang, H., Chen, Y. Su, C.and Cha, Y. (2008), "The Relationship between stock price and EPS: Evidence based on Taiwan panel data," Economic Bulletin, 3(30), 1-12.

16.Collins, D. W., Maydew, E.L. and Weiss, I.S.(1997), "Changes in the value relevance earnings and book value over the past forty years," Journal of Accounting and Economics, 24(1), 39-67.

17.Covill, R. (1998), "Predict the market with earnings per share," Excerpted from An Article originally published in the Issue of Technical Analysis of Stocks\& Commodities Magazine, 1(1), 6.

18.Dontoh, A., Radhakrishnan, S. and Ronen, J. (2001), Is stock price a good measure for assessing value-relevance of earnings? An Empirical Test. Working Paper.

19.Francis, J. and Schipper, K. (1999), "Have Financial Statements lost their relevance? "Journal of Accounting Research, 37(2), 319-352.

20.Frost, C. A. and Powall, G. (1994),"A comparison of the stock price response to earnings disclosures in the United States and the United Kingdom," Contemporary Accounting Research, 11(2), 59-83.

21.Gjerde, O., Knivsfla, K and Saettem, F. (2007), The value-relevance of financial reporting in Norway 1965- 2004, Working Paper.

22.Hausman, J.A. (1978) "Specification Tests in Econometrics," Econometrica, 46(6), 1251-1271.

23. Holthausen, R. W.and Watts, R. L.( 2001), "The Relevance of the ValueRelevance

Literature for Financial Accounting Standard Setting," Journal of Accounting and Economics, 31( 3), 75.

24.Kumo, L.W. (2008) "Stock Exchange in Africa: Prospects and challenge," American Chronicle, 9.

25.Lev, B. and Zarowin, P. (1999), "The boundaries of financial reporting and how to extend them" Journal of Accounting Research, 37(2), 353-385.

26.Meyer, C. (2007), "Shareholder value accounting - the value relevance of Financial Statement data and the determinants of accounting method choices," [Online], [Retrieved October 11, 2009], http://web.research.unizh.ch.

27.Negah, M. (2008) "Liberalisation and the value relevance of accrual accounting information: Evidence from the Johannesburg Securities Exchange," Afro Asian Journal of Finance and Accounting, 1(1), 81 - 104.

28. Nellor, D. C. (2008) “The rise of Africa's "Frontier" markets," Finance and Development, 45(3), 51.

29.0hlson, J.A. (1995) "Earnings, book values and dividends in security valuation," Contemporary Accounting Research, 11(1), 661- 688.

30.0logunde, A.O , Elumilade, D.O. and Asaolu, T.0. (2006), "Stock market capitalization and interest rate in Nigeria: A Time Series Analysis," International Research Journal of Finance and Economics, 4(1).

Adetula Dorcas Titilayo , Obigbemi Imoleayo Salako, Owolabi Folashade and Nwobu Obiamaka (2016), Journal of Accounting and Auditing: Research \& Practice, DOI: 10.5171/2016.252697 
31.0saze, E. B. (2007) Capital markets African and global, the Bookhouse Company, Lagos.

32.Pankoff, L.D. and Virgil, R.L. (1970), "Some preliminary findings from a laboratory experiment on the usefulness of Financial Accounting information to security analysts," Journal of Accounting Research, Empirical Research in Accounting, 8(1), 1-48.

33.Penman, S., (1998) "Combining equity and book value in equity valuation," Contemporary Accounting Research, 1(2), 291-323.

34. Phillip S. K. and M. J. Fetter (1999). Using Multi-Phase Sampling to Limit Respondent Burden across Agriculture Survey," [Online], [Retrieved January 10, 2011],

web.nass.usda.gov/Education_and.../SEQPR oBsgnsp2.pd.

35.Pourheydari, O., Aflatooni, A. and Nikbakhat, Z. (2008), "The Pricing of Dividends and
Book Value in Equity Valuation: The Iran case of Iran," International Research Journal of Finance and Economics,13(1),117.

36.Ramesh, K. and Thiagarajan, R. (1995), Inter-temporal decline in earnings response coefficients, Working Paper, Northwestern University, Evanston, IL.

37.Salmi, T., Virtanen, I., Yli-Olli, P. and Kallunki, J. (1997), Association between accounting and market-based variables. Paper presented in Workshop Financial Statement Analysis University of Vaasa, August.

38.The Nigerian Stock Exchange( 2009). Factbook, 28.

39.Vishnani, S. and Shah, B. (2008), "International differences in the relation between financial reporting decisions and value relevance of published financial statements- with special emphasis on impact of Cash Flow reporting," International Research Journal of Finance and Economics, 17(1), 1450-2887. 